\title{
Kinetic study and removal of contaminants in the leachate treatment using subsurface wetlands at pilot scale
}

\section{Estudio cinético y remoción de contaminantes en el tratamiento de lixiviados empleando humedales subsuperficiales a nivel piloto}

\section{Estudo cinético e remoção de contaminantes no tratamento de lixiviados usando zonas húmidas subsuperfície no nível piloto}

\author{
Fabián A. Úsuga; Andrés F. Patiño; Diana C. Rodríguez; Gustavo A. Peñuela* \\ Grupo Diagnóstico y Control de la Contaminación (GDCON), Escuela Ambiental, Facultad de Ingeniería, Sede de \\ Investigaciones Universitarias (SIU), Universidad de Antioquia (UdeA), Calle 70 No. 52-21, Medellín, Colombia \\ *gustavo.penuela@udea.edu.co
}

Fecha Recepción: 24 de enero de 2017 Fecha Aceptación: 15 de agosto de 2017

\begin{abstract}
The treatment of stabilized leachate from the Curva de Rodas landfill site in Medellin, Colombia, was evaluated using horizontal subsurface flow constructed wetlands (HSSF) planted with Phragmites australis at pilot scale. Assays were performed in two stages: the first with hydraulic loads (q) of 0.015 and $0.030 \mathrm{md}^{-1}$ and the second with loads of 0.060 and $0.091 \mathrm{md}^{-1}$. A wetland without plants was used as a control. Removals of $71.9,91.2$ and $75.1 \%$ for $\mathrm{COD}, \mathrm{BOD}_{5}$ and $\mathrm{NH}_{4}{ }^{+}-\mathrm{N}$, respectively, were obtained. Kinetic constants were determined for each q or hydraulic time retention for $\mathrm{COD}, \mathrm{BOD}_{5}$ and $\mathrm{NH}_{4}{ }^{+} \mathrm{N}^{-}$with ranges into 0.103 and $0.413 \mathrm{~d}^{-1}, 0.065$ and $1.208 \mathrm{~d}^{-1}$, and 0.113 and $0.418 \mathrm{~d}^{-1}$; respectively, in accordance with a first order under piston flow. And by linear regressions had a magnitude of $0.246 \mathrm{~d}^{-1}$ for the removal of COD $\left(R^{2}=0.955\right), 0.299 d^{-1}$ for $\mathrm{NH}_{4}^{+}-\mathrm{N}\left(R^{2}=0.922\right)$ and $0.199 d^{-1}$ for $B O D_{5}\left(R^{2}=0.140\right)$. The elimination of mercury, lead, arsenic and zinc was also evaluated, achieving removals of: $37.8-92.9 \% \mathrm{Hg}, 29.9-$ $44.9 \% \mathrm{~Pb}, 7.9-77.6 \%$ As and $22.9-64.3 \% \mathrm{Zn}$, depending on the hydraulic load applied. The accumulation of these metals in the leaves, stems and roots (rhizomes) of Phragmites australis was found as: $0.575-3.201 \mathrm{mgHgkg}^{-1}, 0.649-4.718 \mathrm{mgPbkg}^{-1}, 3.548-39.376 \mathrm{mgZnkg}^{-1}$, and $19.4 \mathrm{mgAskg}^{-1}$.
\end{abstract}

Keywords: kinetic, leachate, metals, removal, wetland.

\section{Resumen}

Se realizó la evaluación del tratamiento del lixiviado estabilizado del Relleno Sanitario Curva de Rodas de la ciudad de Medellín-Colombia, empleando humedales subsuperficiales de flujo horizontal (HSSF) a nivel piloto plantados con Phragmites australis. Los ensayos fueron realizados en dos etapas, la primera etapa con cargas hidráulicas (q) de 0,015 y $0,030 \mathrm{md}^{-1}$ y en la segunda etapa con 0,060 y $0,091 \mathrm{md}^{-1}$. Un humedal sin plantas como control fue usado. Se obtuvieron remociones del orden de 71,9, 91,2 y 75,1\% para el $\mathrm{COD}, \mathrm{BOD}_{5}$ y $\mathrm{NH}_{4}{ }^{+} \mathrm{-N}$, respectivamente. Se determinaron las constantes cinéticas para cada q o

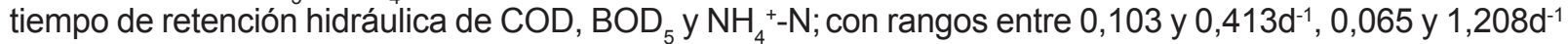
y 0,113 y $0,418 d^{-1}$, respectivamente; según un modelo de primer orden sobre flujo a pistón. Y por regresión lineal se tuvieron magnitudes de $0,246 d^{-1}$ para la $D Q O\left(R^{2}=0,955\right), 0,299 d^{-1}$ para $N_{4}{ }^{+}-N\left(R^{2}=0,922\right)$ y $0,199 \mathrm{~d}^{-1}$ para $\mathrm{DBO}_{5}\left(\mathrm{R}^{2}=0,140\right)$. También se evaluaron las remociones de mercurio, plomo, arsénico y zinc alcanzándose los siguientes rangos de remoción: $37,8-92,9 \% \mathrm{Hg}, 29,9-44,9 \% \mathrm{~Pb}, 7,9-77,6 \% \mathrm{As}$ y 22,9-64,3\%Zn dependiendo de la carga hidráulica aplicada. La acumulación de estos metales en las hojas, tallos y raíces (con rizomas) de las Phragmites australis estuvo en los rangos: $0,575-3.201 \mathrm{mgHgkg}^{-1}$, 0,649-4,718mgPbkg-1 $, 3,548-39,376 \mathrm{mgZnkg}^{-1}$, y de 19,4mgAskg ${ }^{-1}$.

Palabras clave: cinética, humedal, lixiviado, metales, remoción.

Cita: Úsuga FA, Patiño AF, Rodríguez DC, Peñuela GA. Kinetic study and removal of contaminants in the leachate treatment using subsurface wetlands at pilot scale. rev.ion. 2017;30(2):55-63. 


\section{Resumo}

Avaliação do tratamento de lixiviado de aterro estabilizado Curva de Rodas de Medellín, na Colômbia foi realizado utilizando wetlands de fluxo de subsuperfície horizontais (HSSF) a nível piloto plantada com Phragmites australis. Os testes foram realizados em duas etapas, a primeira etapa com as cargas hidráulicas (q) de 0,015 e $0,030 \mathrm{md}^{-1}$ e na segunda etapa com 0,060 e 0,091 $\mathrm{md}^{-1}$. A zona húmida sem plantas foi usado como um controle. Remoção da ordem de 71,9, 91,2 e 75,1\% para CQO, a CBO5 e $\mathrm{NH}_{4}^{+}$, respectivamente, foram obtidos. As constantes cinéticas de $\mathrm{COD}, \mathrm{CBO}_{5}$ and $\mathrm{NH}_{4}{ }^{+} \mathrm{N}$ foram determinados

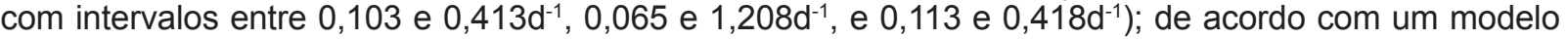
de primeira ordem, sob fluxo de pistão. $E$, por regressão linear, tínhamos magnitudes de $0,246 d^{-1}$ para a $\operatorname{COD}\left(R^{2}=0,955\right), 0,299 d^{-1}$ para $\mathrm{NH}_{4}{ }^{+} \mathrm{N}\left(\mathrm{R}^{2}=0,922\right)$ e $0,199 \mathrm{~d}^{-1}$ para $\mathrm{CBO}_{5}\left(\mathrm{R}^{2}=0,140\right)$. Hg 37.8-92,9\%, 29,9-44,9\% Pb, As 7,9-77,6\% e 22,9-64,3\% Zn, dependendo da carga hidráulica aplicada: a remoção de mercúrio, chumbo, arsênico e zinco atingir os seguintes intervalos de folga também foram avaliadas. O acúmulo desses metais nas folhas, caules e raízes (rizomas) de Phragmites australis estava nos intervalos: $0,575-3,201 \mathrm{mgHgKg}^{-1}, 0,649-4,718 \mathrm{mgPbKg}^{-1}, 3,548-39,376 \mathrm{mgZnKg}^{-1}$, em 19,4mgAsKg-1 .

Palavras chave: cinética, wetland, chorume, metais, remoção.

\section{Introduction}

Leachate from landfills may contain large amounts of organic and inorganic matter, which can be soluble or insoluble in water. The untreated leachate can percolate and reach groundwater sources or mix with surface water and increase contamination [1].

In the Curva de Rodas (RSCR) landfill in Medellin, Colombia is necessary to study treatment alternatives for the leachate generated in a site that was opened since 1984 until 2003. And the constructed wetlands could be functional and implemented as in Canada, Norway, Poland, Slovenia, United Kingdon and USA [2,3].

Constructed wetlands are well-designed and appropriate pretreatment systems that have shown good results in the treatment of domestic sewage, industrial wastewater, mining drainage, agricultural water, leachate and other water with similar characteristics $[1,2,3]$. In wetlands, the degradation of organic matter and nutrients follows a first order kinetics model with hydraulic piston flow behavior [1,4]. Various researchers, like Kadlec and Wallace [5], have made modifications to this kinetic concept. Vymazal et al. [6] made more complex modifications in which linear regressions were used [7]. They employed mathematically more sophisticated methods which take into account the many factors influencing the kinetics of degradation and the transport phenomena of pollutants in wetlands. Such factors include microorganisms, plants, support means (such as gravel), environmental factors and the hydraulic nature of contaminants, among others.
Since 1980 leachate treatment using subsurface horizontal flow wetlands [8] has shown that these systems are effective at removing toxic and recalcitrant residues. At the beginning, leachate from landfills has high pollutant loads of organic and inorganic matter (including heavy metals). However, over time this concentration decreases until it stabilizes $[9,10,11]$. It is at this point that treatment using wetlands becomes more feasible. Colombia has built a lot of wetlands for wastewater treatment, but many of them were designed by people with little knowledge of the subject. As a result, many do not work well or have closed. About 10 years ago at various universities in Colombia, serious studies began regarding water treatment using wetlands [12,13], for domestic wastewater treatment and pesticides as chlorpyrifos. And around the world and present, the wetlands are used to treat many other types of wastewater of industrial applications in combination with other constructed hybrid systems [3].

This study have considerations of the behavior of the wetlands as wastewater treatment systems, including differents conditions of hydraulic time retention and evaluating the removal of COD, $\mathrm{BOD}_{5}$ and $\mathrm{NH}_{4}{ }^{+} \mathrm{N}$; specifically in leachate, contributing with the development in areas of the environmental knowledge with useful importance in a country located in a tropical region.

The main objectives of this study were: a) to evaluate the system efficiency of removal of COD, $\mathrm{BOD}_{5}$ and $\mathrm{NH}_{4}{ }^{+} \mathrm{N}$ of leachate in constructed subsurface wetlands at pilot scale. b) To determine the removal first-order kinetic constants of COD, $\mathrm{BOD}_{5}$ and $\mathrm{NH}_{4}{ }^{+} \mathrm{N}$ at diferents conditions of time 
retention and together with a linear regression. c) To evaluate the removal of heavy metals $(\mathrm{Hg}$, As, $\mathrm{Pb}$ and $\mathrm{Zn}$ ) and their bioaccumulation in the Phragmites australis plants used in the wetlands.

\section{Materials and methods}

\section{Treatment system and experimental design}

The experiment was conducted at the University Research Center (SIU) of the University of Antioquia in the city of Medellin (altitude 1466 meters). Six fiberglass tanks $1.0 \mathrm{~m}$ long, $0.6 \mathrm{~m}$ wide and $0.6 \mathrm{~m}$ deep were used. The support medium used in the wetlands were gravel beds of two particle sizes: a lower bed with $2.7 \mathrm{~mm}$ grains $\left(D_{10}\right)$ and an upper bed with $3.4 \mathrm{~mm}$ grains. Each bed was $0.15 \mathrm{~m}$ thick. The leachate layers of the pilot systems were maintained at a height of $20 \mathrm{~cm}$ and the flow was supplied using $A B B$ flowmeters.
Experiments were carried out over 163 days in two stages (with an average air temperature of $24^{\circ} \mathrm{C}$ ), each with its respective stabilization phase of between 20 and 22 days. During each stage, the wetlands were operated at various flow rates, and with two replicates for each case. Additionally, a wetland without Phragmites australis was employed as a control. Wetlands were named $A, B$, $C$ and $D$ (Table 1), and the equivalences between the retention times were specified (HRTe and HRTn, effective and nominal, respectively). The equivalence in terms of hydraulic head (q) and BA, $B B, B C$ and $B D$ for the case of wetlands without plants or controls were also specified. Porosity was determined by draining the wetlands without Phragmites australis, following the procedure used by Sanford et al. [14], to give a magnitude of 0.32. In each wetland, six species of Phragmites australis were planted evenly distributed.

Table 1. Operating conditions of wetlands.

\begin{tabular}{|c|c|c|c|c|}
\hline Wetlands condition & $\mathrm{ml} \mathrm{min}{ }^{-1}$ & HRTn (d) & HRTe (d) & $q\left(m^{-1}\right)$ \\
\hline \multicolumn{5}{|c|}{ STAGE 1} \\
\hline A & 6.3 & 13.2 & 4.2 & 0.015 \\
\hline B & 12.6 & 6.6 & 2.1 & 0.030 \\
\hline \multicolumn{5}{|c|}{ STAGE II } \\
\hline C & 25.2 & 3.3 & 1.1 & 0.060 \\
\hline D & 37.8 & 2.2 & 0.7 & 0.091 \\
\hline
\end{tabular}

\section{Leachate}

The 40 hectare Curva de Rodas landfill (Table 2 ) is where solid waste from the city of Medellin (Colombia), and other towns near Medellín, was deposited from 1984 to 2003. Due to the fact it was closed in 2003, the leachate used in this study is now stabilized.

Table 2. Characterization of the "Curva de Rodas" leachate.

\begin{tabular}{lll}
\hline Parameter & Units & $\begin{array}{l}\text { Leachate } \\
\text { Average } \pm \text { Std. Dev }\end{array}$ \\
\hline COD & $\mathrm{mgL}^{-1}$ & $642.0 \pm 194.7$ \\
$\mathrm{BOD}_{5}$ & $\mathrm{mgL}^{-1}$ & $115.0 \pm 30.4$ \\
$\mathrm{pH}$ & - & $8.36 \pm 0.20$ \\
Total Alkalinity & $\mathrm{mgCaCO}_{3} \mathrm{~L}^{-1}$ & $3800.83 \pm 504.78$ \\
$\mathrm{NH}_{4}^{+}-\mathrm{N}$ & $\mathrm{mgNL}^{-1}$ & $496.17 \pm 161.87$ \\
$\mathrm{TKN}^{-1}$ & $\mathrm{mgNL}^{-1}$ & $534.97 \pm 176.15$ \\
$\mathrm{TS}$ & $\mathrm{mgL}^{-1}$ & $2951.17 \pm 1272.84$ \\
$\mathrm{DS}$ & $\mathrm{mgL}^{-1}$ & $2623.15 \pm 749.32$ \\
\hline
\end{tabular}

\section{Physicochemical analysis}

Chemical oxygen demand (COD), biochemical oxygen demand $\left(\mathrm{BOD}_{5}\right)$, total solids (TS), disolved solids (DS), ammoniacal nitrogen $\left(\mathrm{NH}_{4}{ }^{+}-\mathrm{NpH}\right.$ and total alkalinity (TA) were analyzed in the laboratory of the University of Antioquia's Diagnosis and Pollution Control Group (GDCON) in accordance with the parameters established in the Standard Methods [15] for the initial characterization (Table 2) of the Curva de Rodas Leachate. And nitrates $\left(\mathrm{NO}_{3}^{-}\right)$, nitrites $\left(\mathrm{NO}_{2}^{-}\right)$, redox potential and $\mathrm{pH}$ were analyzed in the experimentation time with the wetlands. The GDCON laboratory is accredited for wastewater analysis by the Institute of Hydrology, Meteorology and Environmental Studies (IDEAM) of the Colombian Ministry of Environment and Sustainable Development. The metals iron, cadmium, lead, mercury, arsenic and chromium were determined using a GBC 932 plus atomic absorption (AA) instrument with a GBC GF 3000 graphite furnace. The granulometric characterization of the support medium was 
performed by the mechanical method established by ASTM-D421-50 and ASTM-D422-63.

At the end of the study samples of Phragmites australis plants were taken and divided into leaves, stems and roots (including rhizomes) and then dried at room temperature for 4 days. Each of the samples obtained was analyzed for $\mathrm{Pb}, \mathrm{Zn}$, As and $\mathrm{Hg}$. In the analysis of $\mathrm{Pb}, \mathrm{Zn}$, and As the biomass was weighed in crucibles and dried at $100^{\circ} \mathrm{C}$ for 12 hours until a constant weight was achieved. It was then calcined at $450^{\circ} \mathrm{C}$ for $16 \mathrm{~h}$. After that, $2 \mathrm{ml}$ of $2 \mathrm{~N} \mathrm{HNO}_{3}$ was added and acid digestion was performed in a thermostatic plate. It was then further calcined for $1 \mathrm{~h}$ and $5 \mathrm{ml}$ of $2 \mathrm{~N} \mathrm{HNO}_{3}$ and $20 \mathrm{ml}$ of $0.02 \mathrm{~N} \mathrm{H}_{2} \mathrm{SO}_{4}$ were added. Next it was filtered with qualitative paper, diluted to $25 \mathrm{ml}$ and analyzed with the GBC 932 plus instrument (with a GBC GF 3000 graphite furnace). For the analysis of $\mathrm{Hg}$, the biomass was weighed and the following was added: $5 \mathrm{ml}$ of concentrated $\mathrm{H}_{2} \mathrm{SO}_{4}, 2.5 \mathrm{ml}$ of $\mathrm{HNO}_{3}(65 \%), 50 \mathrm{ml}$ of Type 1 water and excess $\mathrm{KMnO}_{4}$. The organic matter was then degraded in a Winkler bottle. The biomass was put in a water bath at $60^{\circ} \mathrm{C}$ for $2 \mathrm{~h}$. Hydroxylamine hydrochloride was added until the biomass was decolorized and it was then filtered. The volume was adjusted to 100 $\mathrm{ml}$ with Type 1 water, and finally it was measured by the AA instrument coupled with a HG3000 GBC cold steam generator.

\section{Kinetic models}

Kinetic constants of the removal of $\mathrm{COD}, \mathrm{BOD}_{5}$ and $\mathrm{NH}_{4}{ }^{+}-\mathrm{N}$ were determined according to the model of Crites et al. [1], which describes the behavior of piston flow and first-order kinetics in the degradation of pollutants in wetlands:

$$
\frac{\mathrm{C}_{0}}{\mathrm{C}_{\mathrm{i}}}=e^{-K_{v} t}
$$

Where:

$\mathrm{C}_{\mathrm{o}}$ and $\mathrm{C}_{\mathrm{i}}$ are the inlet and outlet concentrations $\left(\mathrm{mgL}^{-1}\right)$, respectively.

$t$ is the hydraulic retention time (cash) (EBRT) (d).

$K_{v}$ is the rate constant (Volumetric) $\left(\mathrm{d}^{-1}\right)$.
The kinetic constants of COD, $\mathrm{BOD}_{5}$ and $\mathrm{NH}_{4}{ }^{+} \mathrm{N}$ were calculated individually analyzing the inflow and outflow of each wetland periodically, for the operating conditions described in the Table 1; with the propose of measure repeatability. Along with the average of the $\mathrm{C}_{\mathrm{i}}$ and $\mathrm{C}_{\mathrm{o}}$ concentrations obtained throughout the monitoring and by the linear regression relationship HRTe vs. $\operatorname{Ln}\left(\mathrm{C}_{\mathrm{o}} / \mathrm{C}_{\mathrm{i}}\right)$.

\section{Results and Discussion}

\section{Removal in wetlands}

The best removals of $\mathrm{COD}$ and $\mathrm{NH}_{4}{ }^{+}-\mathrm{N}$ were obtained in the operating condition " $A$ " ( $\left.q=0.015 \mathrm{md}^{-1}\right)$ with average removals of $71.8 \%$ and $71.9 \%$ of COD and $\mathrm{NH}_{4}{ }^{+} \mathrm{N}$, respectively (Table 3 ). The lowest concentrations of $\mathrm{COD}$ and $\mathrm{NH}_{4}{ }^{+}-\mathrm{N}$ in the effluent were $25.2 \mathrm{mgL}^{-1}$ and $27.1 \mathrm{mgL}^{-1}$, respectively, indicating a significant reduction in contamination levels and leachate toxicity. In the case of $\mathrm{BOD}_{5}$, the highest removal was $89.4 \%$, with a concentration of $12 \mathrm{mgL}^{-1}$ in the effluent.

The magnitudes of parameters as DOB in the effluent were relatively low, according with Kadlec [3], because it achieved a secondary and tertiary treatment type, with $\mathrm{BOD}$ ranges into the inflow and outflow of 65 and $30 \mathrm{mgL}^{-1}$, and 30 and $10 \mathrm{mgL}^{-}$ 1 , respectively; decreasing the environment risks during a probably discharge into surface water.

Table 3 shows that wetlands planted with Phragmites australis obtained higher percentages of COD and $\mathrm{NH}_{4}{ }^{+}-\mathrm{N}$ removal compared with the control wetlands. It should be noted that the greater the HRT the longer the interaction time between the pollutants and the microorganisms attached to the rhizomes of the plants and gravel. This allows the microorganisms to better adapt to the support medium, have a greater diversity and a have higher degree of oxygenation. Therefore, the conditions offered by wetland plants lead to a greater removal efficiency of COD and $\mathrm{NH}_{4}^{+}-\mathrm{N}$. In contrast, the control wetlands (BA and $\mathrm{BB}$ ) had higher removals of $\mathrm{BOD}_{5}(91.2 \%$ each) than wetlands $A$ and $B$. This could be due to higher hydraulics time retention where had more contact of facultative microbes that living in association with the substrate and plant roots, because to the microbial control exists when the nutrients loading to the wetland exceeds the hability of the vegetation to utilize it [2], influencing of this way the carbon and nitrogen removal reactions. 
Table 3. Percentage of removal of $\mathrm{COD}, \mathrm{BOD}_{5} \mathrm{y}$ $\mathrm{N}-\mathrm{NH}_{4}{ }^{+}$in each wetland monitored.

\begin{tabular}{cccc}
\hline \multirow{2}{*}{ Wetland } & \multicolumn{3}{c}{ Average Removal (\%) } \\
& COD & BOD $_{5}$ & NH $_{4}^{+}-\mathbf{N}$ \\
\hline A & 71.8 & 71.2 & 71.9 \\
B & 53.3 & 89.4 & 55.3 \\
C & 33.4 & 28.8 & 33.6 \\
D & 29.6 & 50.8 & 21.2 \\
BA & 53.5 & 91.2 & 53.1 \\
BB & 50.1 & 91.2 & 39.9 \\
BC & 17.8 & 23.2 & 20.3 \\
BD & 15.0 & 40.0 & 14.3 \\
\hline
\end{tabular}

The levels of redox potential within the wetlands oscillated from $248 \mathrm{mV}$ to $193 \mathrm{mV}$, suggesting that oxidative conditions were the mechanisms of greatest influence on the removal of COD and $\mathrm{NH}_{4}{ }^{+}-\mathrm{N}$. In the case of $\mathrm{NH}_{4}{ }^{+}-\mathrm{N}$, this is confirmed by the $\mathrm{NO}_{2}^{-}$value of $42.866 \mathrm{mgL}^{-1}$ and the $\mathrm{NO}_{3}{ }^{-}$value of $133.455 \mathrm{mgL}^{-1}$ obtained in the effluent. The $\mathrm{pH}$ decreased from about 8.8 in the affluent to 7.8 in the effluent, which indicates alkalinity consumption by nitrification processes.

\section{Kinetic constants}

Table 4 shows the values of $\mathrm{Kv}$ for the removal of COD, $\mathrm{BOD}_{5}$ and $\mathrm{NH}_{4}{ }^{+}-\mathrm{N}$, which ranged from 0.115 to $0.401 \mathrm{~d}^{-1}, 0.099-1.121 \mathrm{~d}^{-1}$ and $0.114-0.402 \mathrm{~d}^{-1}$, respectively. These ranges are extensive because they were obtained with wetlands under different operating conditions.

Table 4. Kinetic constants for the removal of $\mathrm{COD}, \mathrm{BOD}_{5}$ and $\mathrm{NH}_{4}{ }^{+}-\mathrm{N}$ determined with equation.

\begin{tabular}{|c|c|c|c|c|c|c|c|c|c|}
\hline \multirow[t]{2}{*}{ Wetland } & \multicolumn{3}{|c|}{$\begin{array}{l}\text { COD } \\
\left(d^{-1}\right)\end{array}$} & \multicolumn{3}{|c|}{$\begin{array}{c}\mathrm{BOD}_{5} \\
\left(\mathrm{~d}^{-1}\right)\end{array}$} & \multicolumn{3}{|c|}{$\begin{array}{c}\mathrm{NH}_{4}{ }^{+}-\mathrm{N} \\
\left(\mathrm{d}^{-1}\right)\end{array}$} \\
\hline & $\mathrm{K}_{\mathrm{v}}$ & $\mathrm{K}_{\mathrm{V} \text { Prom }}$ & $\sigma$ & $\mathrm{K}_{\mathrm{v}}$ & $\mathrm{K}_{\mathrm{v} \text { Prom }}$ & $\sigma$ & $\mathrm{K}_{\mathrm{v}}$ & $\mathbf{K}_{\mathrm{V} \text { Prom }}$ & $\sigma$ \\
\hline $\mathrm{A} 1$ & 0.287 & \multirow{2}{*}{0.282} & \multirow{2}{*}{0.008} & 0.313 & \multirow{2}{*}{0.290} & \multirow{2}{*}{0.032} & 0.310 & \multirow{2}{*}{0.290} & \multirow{2}{*}{0.028} \\
\hline A2 & 0.276 & & & 0.268 & & & 0.270 & & \\
\hline B1 & 0.390 & \multirow{2}{*}{0.401} & \multirow{2}{*}{0.017} & 1.035 & \multirow{2}{*}{1.121} & \multirow{2}{*}{0.122} & 0.418 & \multirow{2}{*}{0.402} & \multirow{2}{*}{0.022} \\
\hline B2 & 0.413 & & & 1.208 & & & 0.387 & & \\
\hline $\mathrm{C} 1$ & 0.128 & \multirow{2}{*}{0.115} & \multirow{2}{*}{0.018} & 0.065 & \multirow{2}{*}{0.099} & \multirow{2}{*}{0.049} & 0.115 & \multirow{2}{*}{0.114} & \multirow{2}{*}{0.001} \\
\hline $\mathrm{C} 2$ & 0.103 & & & 0.134 & & & 0.113 & & \\
\hline D1 & 0.257 & \multirow{2}{*}{0.222} & \multirow{2}{*}{0.049} & 0.421 & \multirow{2}{*}{0.458} & \multirow{2}{*}{0.064} & 0.151 & \multirow{2}{*}{0.147} & \multirow{2}{*}{0.005} \\
\hline D2 & 0.187 & & & 0.330 & & & 0.143 & & \\
\hline
\end{tabular}

The kinetic constants for the removal of COD, $\mathrm{BOD}_{5}$ and $\mathrm{NH}_{4}{ }^{+}-\mathrm{N}$ (Table 4) had a higher magnitude in wetland $B\left(0.401 d^{-1}, 1.121 d^{-1}\right.$ and $0.402 d^{-1}$, respectively) than wetland $A\left(0.282 d^{-1}, 0.290 d^{-1}\right.$ and $0.290 d^{-1}$, respectively). However, wetland $B$ had a HRTn of $6.6 \mathrm{~d}$, which was lower than the HRTn for wetland $A(13.2 d)$, but higher than wetlands $C$ and $\mathrm{D}$ (3.3d 2.2d, respectively). According to the above, a high value of $\mathrm{Kv}$ does not require long retention times with leachates. However, it probably does need a large microbial population in the gravel and roots of the plants to degrade the pollutants. And possibly the microbial population would had best conditions for growing at HRTn of $6.6 \mathrm{~d}$ for wetland $\mathrm{B}$ accelerating the kinetic of nitrogen (as $\mathrm{NH}_{4}{ }^{+} \mathrm{N}$ ) and organic matter; and later until $13,2 d$ the microorganisms went into a renovation and adaptation stage for the degradation of the more resistant and recalcitrant compounds of the leachate at higher time [11].

Standard deviations $(\sigma)$ (Table 4 ) of the $\mathrm{Kv}$ measurements indicate that there was good repeatability in the kinetics $\mathrm{COD}$ and $\mathrm{NH}_{4}{ }^{+} \mathrm{N}$ removal. Repeatability was less significant for $\mathrm{BOD}_{5}$ removal, possibly due to the range of variation of the test in the laboratory. The kinetic constants determined with linear regressions (Table 5) had a magnitude of $0.246 \mathrm{~d}^{-1}$ for the removal of COD $\left(R^{2}=0.955\right), 0.299 d^{-1}$ for $\mathrm{NH}_{4}{ }^{+}-\mathrm{N}$ $\left(R^{2}=0.922\right)$ and $0.199 d^{-1}$ for $B_{5} D_{5}\left(R^{2}=0.140\right)$, with $1.5<\mathrm{q}\left(\mathrm{cm} \mathrm{d}^{-1}\right)<9.1$. The results were more similar with the constants determined individually for the A wetlands, but a lower correlation with $\mathrm{BOD}_{5}$ was obtained. 
rev.ion. 2017;30(2):55-63. Bucaramanga (Colombia).

Table 5. Kinetic constants for the removal of $\mathrm{COD}, \mathrm{BOD}_{5}$ and $\mathrm{NH}_{4}{ }^{+} \mathrm{N}$ determined for lineal regression.

\begin{tabular}{|c|c|c|c|c|c|c|}
\hline Humedal & $\operatorname{Ln}(\mathrm{Ci} / \mathrm{Co})$ & TRHe (d) & Parámetro & Ecuación & $\mathbf{R}^{2}$ & $K_{v}\left(d^{-1}\right)$ \\
\hline$A$ & 1.19 & 4.2 & \multirow{4}{*}{ COD } & \multirow{4}{*}{$\operatorname{Ln}\left(C_{i} / C_{o}\right)=0.246 \mathrm{HRTe}+0.193$} & \multirow{4}{*}{0.955} & \multirow{4}{*}{0.246} \\
\hline B & 0.81 & 2.0 & & & & \\
\hline C & 0.40 & 1.1 & & & & \\
\hline $\mathrm{D}$ & 0.34 & 0.7 & & & & \\
\hline$A$ & 1.23 & 4.2 & \multirow{4}{*}{$\mathrm{BOD}_{5}$} & \multirow{4}{*}{$\operatorname{Ln}\left(C_{i} / C_{0}\right)=0.199 \mathrm{HRTe}+0.737$} & \multirow{4}{*}{0.140} & \multirow{4}{*}{0.199} \\
\hline B & 2.26 & 2.0 & & & & \\
\hline C & 0.35 & 1.1 & & & & \\
\hline $\mathrm{D}$ & 0.71 & 0.7 & & & & \\
\hline$A$ & 1.23 & 4.2 & \multirow{4}{*}{$\mathrm{NH}_{4}^{+}-\mathrm{N}$} & \multirow{4}{*}{$\operatorname{Ln}\left(C_{i} / C_{o}\right)=0.299 \mathrm{HRTe}+0.023$} & \multirow{4}{*}{0.922} & \multirow{4}{*}{0.299} \\
\hline B & 0.81 & 2.0 & & & & \\
\hline C & 0.22 & 1.1 & & & & \\
\hline $\mathrm{D}$ & 0.23 & 0.7 & & & & \\
\hline
\end{tabular}

Rousseau et al. [7] obtained a series of kinetic removal constants under different conditions with a $B O D_{5}$ variation range of $0.17 d^{-1}$ to $6.11 d^{-1}$. The $\mathrm{BOD}_{5}$ constant obtained in this study by linear regression $\left(0.199 d^{-1}\right)$ and the Kv determined individually $\left(0.099 \mathrm{~d}^{-1}-1.121 \mathrm{~d}^{-1}\right)$ are within the range established by Rousseau et al. [7]. Jing and Lin [16] gave a summary of nitrogen removal constants obtained by different authors using subsurface wetlands, showing values between $0.411 \mathrm{~d}^{-1}-0.126 \mathrm{~d}^{-1}$. The values of $\mathrm{NH}_{4}{ }^{+}-\mathrm{N}$ kinetic removal constants from individual analyzes (Table 4) and linear regression (Table 5) found in this study are within the ranges reported in other research. In the A wetlands, kinetic constants were derived that were very similar to those established by linear regression for COD $\left(0.282 \mathrm{~d}^{-1}\right.$ and $0.246 \mathrm{~d}^{-1}$, respectively) and $\mathrm{NH}_{4}{ }^{+}-\mathrm{N}$ $\left(0.290 \mathrm{~d}^{-1}\right.$ and $0.299 \mathrm{~d}^{-1}$, respectively), bearing in mind that under these conditions the highest removal efficiencies were obtained.

In terms of leachate treatment, Metcalf and Eddy [11] suggested that for the degradation of toxic and recalcitrant compounds, it is necessary for the microorganisms to be acclimated and conditioned to this type of substance for an appropriate time. In this study such measures were carried out using wetlands where the loads to be treated were controlled, as seen in Tao et al. [17]. The effective operation of wetlands depends on the hydraulic and organic load, as well as the physiochemical $(\mathrm{pH}$, redox potential) and biological (size of microbial population) conditions, since these factors favour the transformation of contaminants.

\section{Removal of heavy metals in wetlands}

The monitoring of metals in the leachate showed that the concentrations of chromium and copper were very low, less than $0.083 \mathrm{mgL}^{-1}$ and $0.042 \mathrm{mgL}^{-1}$ in the influent and $0.050 \mathrm{mgL}^{-1}$ and $0.025 \mathrm{mgL}^{-1}$ in the effluent, respectively. For lead, a maximum concentration in the influent of $0.313 \mathrm{mgL}^{-1}$ and a minimum in the effluent of $0.108 \mathrm{mgL}^{-1}$ was found, yielding an overall average of $29.9 \%$ removal. In the case of mercury, removals were obtained from $37.8 \%$ to $96.2 \%$ in the first stage, and $54.5 \%$ to $92.9 \%$, in the second, for influent concentrations of $5.92 \mathrm{mgL}^{-1}$ to $56.12 \mathrm{mgL}^{-1}$, and $9.00 \mathrm{gL}^{-1}$ to $16.00 \mathrm{mgL}^{-1}$, respectively. In the case of zinc, in the first stage, the maximum concentration in the effluent was $0.073 \mathrm{mgL}^{-1}$, with a maximum removal of $64.3 \%$. In contrast, for the second stage, removal reached $22.9 \%$ with an affluent concentration of $0.054 \mathrm{mgL}^{-1}$. The observed decline is due to an increased HRT, which resulted in a shorter time for this metal to be assimilated by plants. The removals obtained in this study are consistent with the results reported by Kröpfelová et al. [18] who used constructed wetlands for wastewater treatment and obtained removals between $25.7 \%-84.2 \%$ for lead, $58.3 \%$ $-90.5 \%$ for zinc and $29.4 \%-47.4 \%$ for mercury. The maximum arsenic removal in the first stage was $77.6 \%$, while in the second stage it was $70.4 \%$. The removal of metals in wetlands may be because of plant uptake, adsorption onto the gravel and plants, and precipitation. All of these processes are favored by increasing the HRTn to times longer than 6.6 days. 


\section{Heavy metal accumulation in plants}

The zinc content in the Phragmites australis was $39.38 \mathrm{mgkg}^{-1}$ in the leaves, $3.55 \mathrm{mgkg}^{-1}$ in the stem, and $13.72 \mathrm{mgkg}^{-1}$ in the roots and rhizomes. This means that a total of $69.5 \%$ of zinc was retained in the leaves (Figure 1). Lead accumulation was $4.72 \mathrm{mgkg}^{-1}$ in the leaves, $0.65 \mathrm{mgkg}^{-1}$ in the stem, and $1.07 \mathrm{mgkg}^{-1}$ in the roots and rhizomes. Therefore, again the highest concentrations were in the leaves, within the composition of the plant, giving an accumulation percentage of $73.3 \%$ (Figure 2). Values can be compared for the treatment of wastewater reported by Vymazal et al. $[6,19]$, with levels of $0.22 \mathrm{mgkg}^{-1}$ in leaves and $0.13 \mathrm{mgkg}^{-1}$ in stems, and data taken by Vymazal et al. [19] where concentrations were between 0.09 and $0.21 \mathrm{mgkg}^{-1}$ in the leaves and stems, 2.5 to $8.0 \mathrm{mgkg}^{-1}$ in the roots, and 0.7 to $12.2 \mathrm{mgkg}^{-1}$ in rhizomes. It can be seen that lead concentrations detected in this study were consistent with data reported in the literature, as both show that the highest lead content is in the leaves.

Mercury concentrations in this study were $1.21 \mathrm{mgkg}^{-1}$ in the leaves, $0.58 \mathrm{mgkg}^{-1}$ in the stem, and $3.20 \mathrm{mgkg}^{-1}$ in the roots and rhizomes (Figure $3)$. Therefore, the highest content of $\mathrm{Hg}(24.2 \%)$ was absorbed in the root zone. This indicates that mercury is less mobile than $\mathrm{Zn}$ and $\mathrm{Pb}$, and thus, stays in the roots and rhizomes. In terms of the accumulation percentages of heavy metals present in the plants, the leaves had highest lead and zinc content (73.3 and $69.5 \%$, respectively), while the stem had lower percentages of lead, zinc and mercury $(10.1,6.3$ and $11.5 \%$, respectively). According to the above, the $\mathrm{Pb}$ and $\mathrm{Zn}$ were most concentrated in the leaves and roots of the plants, and less so in the stems. In contrast, the concentrations of mercury were highest in the roots, then in the leaves and finally in the stems. These results were similar to those obtained by Vymazal et al. [6,19]. In conclusion, in this study it was found that the concentrations of metals in the biomass of Phragmites australis were highest for Lead and Zinc, and lowest for mercury.

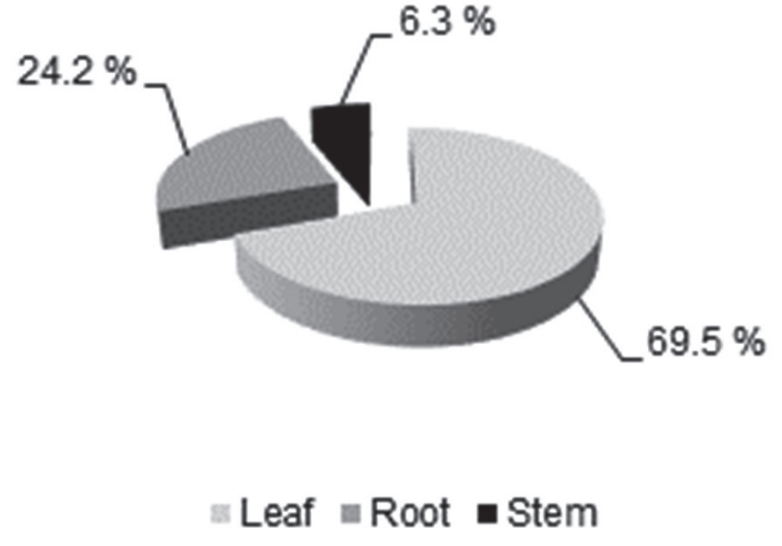

Figure 1. Percentage of zinc accumulated in plants.

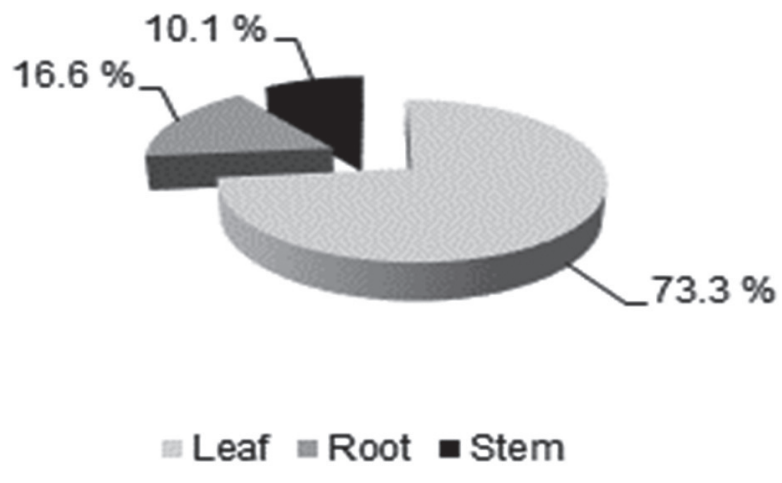

Figure 2. Percentage of lead accumulated in plants.

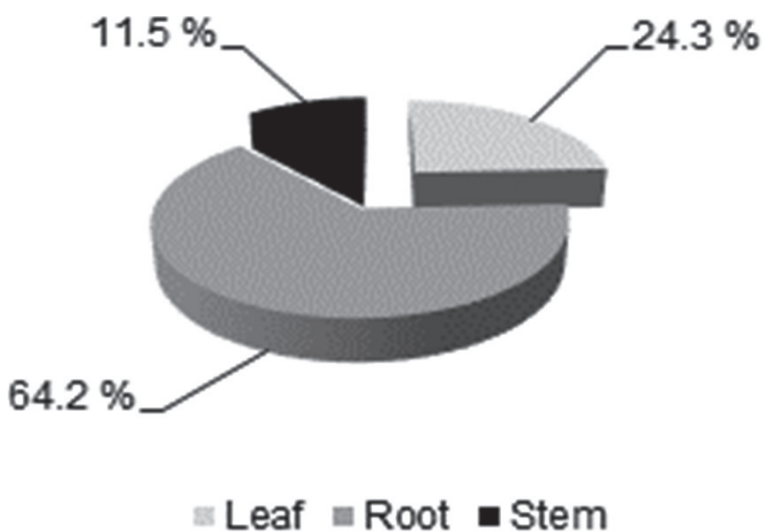

Figure 3. Percentage of mercury accumulated in plants. 
Kadlec and Zmarthie [8] studied too the storage and accumulation of trace metals in wetland plants in contact with leachate from a close landfill, where have been shown to accumulate metals in above and below ground tissues, but those amounts are minor in comparison to the sequestered in sedimentation. But an alternative to dispose the plants could be incineration.

\section{Conclusion}

High removal percentages of $\mathrm{COD}$ and $\mathrm{NH}_{4}{ }^{+}-\mathrm{N}$ of 71.9 and $75.1 \%$, respectively, were achieved. Heavy metals were also efficiently removed from the water $(37.8-92.9 \%$ of $\mathrm{Hg}, 29.9-44.9 \%$ of $\mathrm{Pb}, 7.9-$ $77.6 \%$ and $22.9-64.3 \%$ of $\mathrm{Zn}$ and As, respectively), which then accumulated in the leaves, stems and roots (rhizomes) of the Phragmites Australis (0.575-3.201 $\mathrm{mgHgkg}^{-1}, \quad 0.649-4.718 \mathrm{mgPbkg}^{-1}$, $3.548-3.9376 \mathrm{mgZnkg}^{-1}$, and $19.4 \mathrm{mgAskg}^{-1}$ only in the stem ). For the treatment of leachate in tropical conditions, the kinetic constants of $\mathrm{COD}, \mathrm{BOD}_{5}$ and $\mathrm{NH}_{4}^{+}-\mathrm{N}$ removal, determined individually, were $0.103-$ $0.413,0.065-1.208$ and $0.113-0.418 d^{-1}$, respectively. Those obtained from linear regressions were 0.246 , 0.199 and $0.299 \mathrm{~d}^{-1}$, respectively, according to the basic first order model and piston flow.

\section{Acknowledgements}

The authors wish to thank the GDCON group and the Sustainability Research Fund of the 2015-2016 administration of the University of Antioquia for funding the project.

\section{References}

[1] Crites RW, Middlebrooks J, Reed S.C. Natural Wastewater Treatment Systems. Slovakia: Taylor \& Francis Group; 2014.

[2] Kadlec RH. Comparison of free water and horizontal subsurface treatment wetlands. Ecol. Eng. 2009;35:159-74.

[3] Vymazal J. Review. The use constructed wetlands with horizontal sub-surface flow for various types of wastewater. Ecol. Eng. 2009;35:1-17.

[4] Brix $\mathrm{H}$. Use of constructed wetlands in water pollution control: Historical development, present status, and future perspectives. Water Sci. Technol. 1994;30:209-33.
[5] Kadlec R, Wallace S. Treatment Wetlands. Florida: Taylor \& Francis Group; 2009.

[6] Vymazal J, Kröpfelová L, Švehla J, Chrastný V, Štíchová J. Trace elements in Phragmites australis growing in constructed wetlands for treatment of municipal wastewater. Ecol. Eng. 2009;35:303-09.

[7] Rousseau DPL, Vanrolleghem PA, Pauw ND. Model-based design of horizontal subsurface flow constructed treatment wetlands: a review. Water Res. 2004;38:1484-93.

[8] Kadlec RH, Zmarthieb LA. Wetland treatment of leachate from a closed landfill. Ecol. Eng. 2010;36:946-57.

[9] Tchobanoglous G, Theisen H, Vigil S. Integrated solid waste management: engineering principles and management issues. New York: McGraw Hill; 1993.

[10] McBean EA, Rovers F. Landfill leachate characteristics as inputs for the design of wetlands. In: Mulamoottil G, McBean EA, Rovers F. Constructed Wetlands for the Treatment of Landfill Leachates. Florida: Lewis Publishers; 1999.

[11] Metcalf and Eddy. Wastewater Engineering: Treatment and Reuse. New York: McGraw-Hill; 2003.

[12] Peña MR, Van Ginneken M, Madera C. Subsurface flow constructed wetlands: a natural alternative for domestic wastewater treatment in tropical regions. Eng. Compet. J. 2003;5(1):2735.

[13] Agudelo RM, Peñuela G, Aguirre NJ, Morató $\mathrm{J}$, Jaramillo ML. Simultaneous removal of chlorpyrifos and dissolved organic carbon using horizontal sub-surface flow pilot wetlands. Ecol. Eng. 2010;36:1401-8.

[14] Sanford W, Steenhuis T, Parlange J, Surface J, Peverly J. Hydraulic conductivity of gravel and sand as substrates in rock-reed filters. Ecol. Eng. 1995;4:321-36.

[15] APHA, AWWA, WPCF. Standard Methods for the Examination of Water and Wastewater. Washington, DC; 2012.

[16] Jing RJ, Lin YF. Seasonal effect on ammonia nitrogen removal by constructed wetlands treating polluted river water in southern Taiwan. Environ. Pollut. 2004;127:291-301.

[17] Tao W, Hall KJ, Duff SJB. Performance evaluation and effects of hydraulic retention 
time and mass loading rate on treatment of woodwaste leachate in surface-flow constructed wetlands. Ecol. Eng. 2006:6;252-65.

[18] Kröpfelová L, Vymazal J, Švehla J, Štíchová J. Removal of trace elements in three horizontal subsurface flow constructed wetlands in the Czech
Republic. Environ. Pollut. 2009:157;1186-94.

[19] Vymazal J, Švehla J, Kröpfelová L, Chrastný V. Trace metals in Phragmites australis and Phalaris arundinacea growing in constructed and natural wetlands. Science of the Total Environment. 2007:380;154-62. 